\title{
EVIDENCE FOR PERIAQUEDUCTAL CHOLECYSTOKININ- SUBSTANCE P NEURONS PROJECTING TO THE SPINAL CORD ${ }^{1}$
}

\author{
L. SKIRBOLL, ${ }^{* 2}$ T. HÖKFELT, $\ddagger$ G. DOCKRAY,§ J. REHFELD, $\|$ M. BROWNSTEIN, AND \\ A. C. CUELLOI \\ * Neuroscience Branch and Laboratory of Clinical Science, National Institute of Mental Health, Bethesda, Maryland 20205; \\ $\ddagger$ Department of Histology, Karolinska Institute, S-10401 Stockholm, Sweden; \& Department of Physiology, University of \\ Liverpool, Liverpool, England; || Department of Biochemistry, University of Copenhagen, Copenhagen, Denmark; and \\ I| Department of Pharmacology, Oxford University, Oxford, England
}

Received September 27, 1982; Revised December 27, 1982; Accepted January 5, 1983

\begin{abstract}
Using indirect immunofluorescence techniques combined with retrogradely transported fluorescent dyes, cholecystokinin (CCK)-like and substance P immunoreactive cell bodies in the periaqueductal central grey of the rat brain were studied. Data from both adjacent sections and elutionrestaining techniques indicated that some of these central grey cells contain both a CCK-like peptide and substance $P$. Injection of the fluorescent dye, Fast Blue, into the cervical spinal cord indicated that this CCK-substance $P$ cell group is a descending system. These findings provide evidence for two peptides in a single neuron, and the possible functional significance of such an occurrence is discussed.
\end{abstract}

Peptides are widely distributed in the peripheral and central nervous system (Hökfelt et al., 1980a), and they may play a physiological role as neurotransmitters (Otsuka and Takahasi, 1977; Snyder, 1980). Substance P (Von Euler and Gaddum, 1931; Chang et al., 1971) is present in many cell groups in the central nervous system of the rat (Ljungdahl et al., 1978), one of which is located in the periaqueductal central grey at the border between hypothalamus and mesencephalon. These substance $\mathrm{P}$ immunoreactive cells are large multipolar cells with a diameter of about 25 to $35 \mu \mathrm{m}$. Gastrin/cholecystokinin (CCK)-like peptides also have a wide distribution in the central nervous system and, similar to that of substance $\mathrm{P}$, have been shown in immunocytochemical studies to be present in a group of large neurons in the periaque-

\footnotetext{
1 This work was supported in part by the Swedish Medical Research Council (SMRC) Grant 04X-2887, Magnus Bergvalls Stiftelese, Knut och Alice Wallenbergs Stiftese, and the Welcome Trust (A. C. C.). We would like to express our thanks to Drs. Otto Dann and H. G. J. M. Kuypers for generously supplying the Fast Blue. The expert technical assistance of Ms. W. Hiort and Ms. Annika Edin are gratefully acknowledged. Our thanks are also extended to Ms. B. Frideen, Ms. Dottie Drake, and Ms. Nell Brock for their expert secretarial help. Part of this work was carried out during a stay of Thomas Hökfelt at the National Institutes of Health as a Fogarty Fellow. The Fellowship is gratefully acknowledged.

${ }^{2}$ To whom correspondence should be addressed at Clinical Neuroscience Branch, National Institute of Mental Health, Building 10, Room 3N-256, Bethesda, MD 20205.
}

ductal grey (Vanderhaeghen et al., 1975, 1980; Innis et al., 1979; Larsson and Rehfeld, 1979; Loren et al., 1979; Hökfelt et al., 1980a, b, c).

In the present study, the relationship between these substance $P$ and CCK-like immunoreactive cell groups was explored by examining either adjacent sections, each stained with either substance $\mathrm{P}$ or $\mathrm{CCK}$ antibodies, or the same section sequentially stained with both antibodies and using the elution-restaining technique of Tramu et al. (1978). In addition, using a technique by which retrograde tracing with fluorescent dyes (Kuypers et al., 1977) is combined with indirect immunofluorescence histochemistry (Hökfelt et al., 1979; Skirboll et al., 1982a; Skirboll and Hökfelt, 1983), the projections of these substance $\mathrm{P}$ and CCK immunoreactive cell groups were analyzed. A preliminary report has appeared (Skirboll et al., 1982b).

\section{Materials and Methods}

Male, albino rats (Sprague-Dawley, body weight 150 gm) were used. Fast Blue (253/50) was injected into the upper part of the cervical spinal cord of 10 animals. Three days later the rats received an intraventricular injection of colchicine $(60 \mu \mathrm{g}$ in $20 \mu \mathrm{l}$ of $0.9 \%$ sodium chloride). After $25 \mathrm{hr}$ the rats were perfused with ice-cold $10 \%$ formalin in $0.1 \mathrm{~m}$ phosphate buffer for $30 \mathrm{~min}$. The brains were rapidly dissected out and immersed in the same fixative for $90 \mathrm{~min}$ and then rinsed in $0.1 \mathrm{M}$ phosphate buffer with 5\% sucrose added. Frontal sections of 
the caudal hypothalamus and rostral mescencephalon were cut on a cryostat (Dittes, Heidelberg, Federal Republic of Germany) (section thickness 5, 10, or $14 \mu \mathrm{m}$ ). The sections were analyzed in a fluorescence microscope, and Fast Blue-labeled cells were photographed. Then the sections were processed for indirect immunofluorescence according to Coons and collaborators (see Coons, 1958) as described in more detail elsewhere (see Hökfelt et al., 1980c). Briefly, adjacent sections were incubated with antiserum to substance $P$ (see Cuello et al., 1980) or CCK (see Dockray et al., 1981; Rehfeld, 1981) in a humid atmosphere at $4^{\circ} \mathrm{C}$ for 14 to $20 \mathrm{hr}$, rinsed in phosphatebuffered saline (PBS), incubated with rhodamine-conjugated sheep antirabbit antibodies (or antirat antibodies for substance $\mathrm{P}$ ) for $30 \mathrm{~min}$ at $37^{\circ} \mathrm{C}$ in a humid atmosphere, rinsed in PBS, and mounted in a mixture of glycerin and PBS (3:1). The sections were examined in a fluorescence microscope. Elution-restaining experiments were carried out according to Tramu et al. (1978). Briefly, after examination and photography of the CCK-like immunoreactivity, the sections were rinsed and treated with a mixture of potassium permanganate $\left(\mathrm{KMnO}_{4}\right)$ and sulphuric acid $\left(\mathrm{H}_{2} \mathrm{SO}_{4}\right)$ for 30 to $60 \mathrm{sec}$. The sections were examned in the fluorescence microscope, and, provided that no fluorescence was observed, they were incubated with fluorescein isothiocyanate-conjugated antibodies for $30 \mathrm{~min}$ at $37^{\circ} \mathrm{C}$ and examined again. If no fluorescence was seen, the sections were incubated with substance $\mathrm{P}$ antiserum followed by rhodamine-conjugated antibodies and analyzed in the fluorescence microscope and photographed. The filters used in the fluorescence microscope were as follows: for Fast Blue, Schott UG 1 and Zeiss 41 as primary and secondary filters, respectively; for rhodamine-induced fluorescence, Schott BP 546 and LP 590, respectively. Details on the combined retrograde tracing and immunofluorescence procedures and on the restaining technique have been described elsewhere (Skirboll et al., 1982a, Skirboll and Hökfelt, 1983).

\section{Results}

After incubation of sections from the caudal hypothalamic-rostral mesencephalic level of colchicine-treated rats, numerous strongly CCK-like immunoreactive cell bodies were observed in the ventral, central part of the periaqueductal grey with single cells close to the aqueduct. The cells were often elongated with the long axis running in the ventral-dorsal direction. One or two, and occasionally more, processes could be identified in 10 to $14 \mu \mathrm{m}$ thick sections. The 15 to 30 cell profiles which could be observed in a single section formed a distinct group in which a midline cell group could be seen along with several bilateral cells positioned in the more ventrolateral aspects of the central grey. In adjacent sections stained with antisera to substance $P$, cells with a distribution similar to CCK-immunoreactive neurons were observed. The number of these cells as well as their morphological features and topography were very similar to those of CCK-stained neurons.

To determine whether the same neurons were immunoreactive to both CCK-like and substance $\mathrm{P}$ antisera, micrographs of $5 \mu$ thick adjacent sections stained with
CCK and substance $P$ antisera, respectively, were compared. Data from this analysis provided strong evidence that, at least in some cases, CCK- and substance Pcontaining cells were identical (Fig. 1, $D$ and $E$ ). In an effort to more rigorously test this finding, single sections (10 to $14 \mu \mathrm{m}$ thickness) were first stained for CCK-like immunoreactivity, photographed, and subsequently treated to remove the CCK antiserum (see "Materials and Methods"). This same section was then restained with substance $P$ antiserum and photographed. Careful examination of these micrographs revealed that many cells did, indeed, contain both substance P and CCK-like immunoreactivity. It also was not possible to carry out the reverse experiment, i.e., to restain with CCK antiserum after the elution of substance $P$ antiserum. This may be due to the fact that potassium permanganate destroys the antigenicity of CCK. In addition, although other systems which were either CCK-like or substance $\mathrm{P}$ immunoreactive were observed in the same sections, there was no evidence that these cell bodies and/or nerve terminals were the same.

In the next series of studies, indirect immunofluorescence was combined with a fluorescent retrograde tracing technique in an effort to determine the projections of this CCK-substance $P$ cell group. After injection of Fast Blue into the cervical spinal cord, approximately at the level of $\mathrm{C}_{5}$, blue fluorescent cell bodies were observed in the periaqueductal central grey in areas coincidental with the neurons which proved immunoreactive to both CCK and substance $P$ antisera. It should be mentioned that cervical dye injections resulted in labeled cells in many other areas of the brain, but this study will be limited to the cell group of interest located in the mesencephalic periaqueductal central grey. Sections in which labeled cells were visualized in the periaqueductal grey were photographed, and the same section was subsequently processed for indirect immunocytochemistry. After processing, comparison of micrographs of retrograde fluorescence with immunofluorescence established that some of the cells labeled with dye were also CCK and substance $\mathrm{P}$ immunoreactive (Fig. 1, $A$ to $E$ ). This procedure could be followed with either semıddjacent sections or the elution-restaining technique (for methods see Skirboll and Hökfelt, 1983; Skirboll et al., 1982a).

After incubation with control antisera, i.e., CCK and substance $P$ antiserum absorbed with an excess of CCK and substance $P$, respectively, none of the cell bodies described above were observed. Furthermore, absorption of CCK antiserum with an excess of substance $\mathrm{P}$ or, alternatively, absorption of substance $P$ antiserum with an excess of CCK-7, did not abolish the fluorescence induced by the absorbed antisera.

\section{Discussion}

The present findings confirm earlier evidence for the occurrence of both substance P (Ljungdahl et al., 1978) and CCK (Innis et al., 1979; Larsson and Rehfeld, 1979; Loren et al., 1979; Hökfelt et al., 1980a, b, c; Vanderhaeghen et al., 1980) immunoreactive cells in the ventral, central part of the hypothalamic-mesencephalic periaqueductal central grey. The present study, in addition, demonstrates that at least some of the cells in this region 

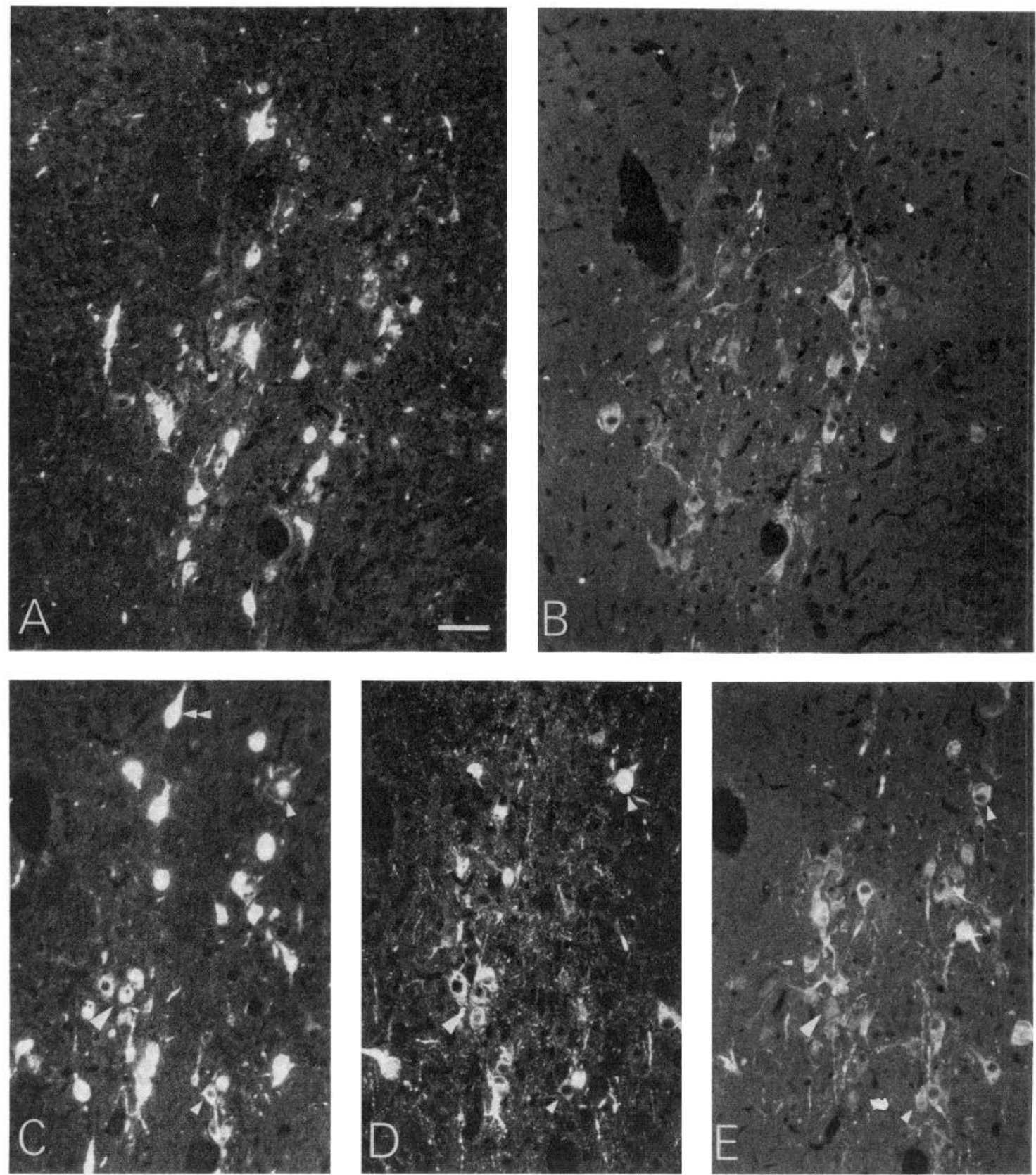

Figure 1. Fluorescence ( $A$ and $C$ ) and immunofluorescence $(B, D$, and $E$ ) micrographs of frontal plane sections of the ventral, medial aspects of the anterior periaqueductal central grey of colchicine-treated rat injected with Fast Blue into the spinal cord. $A$ and $B$, on one hand, and $C$ and $D$, on the other hand, show the same section. These two sections are semiconsecutive, whereas $E$ shows a section immediately adjacent to the one shown in $C$ and $D$. $B$ and $E$ have been incubated with CCK and $D$ with substance $\mathrm{P}$ antiserum. Most of the cells retrogradely labeled with Fast Blue are CCK (compare $A$ and $B$ ) and substance $\mathrm{P}$ (compare $C$ and $D$ ) positive. In $C$ to $E$ several cells (small arrowheads) can be seen which contain Fast Blue, CCK-, and substance P-like immunoreactivity. Large arrowheads point to a group of identical cells. The bar indicates $50 \mu \mathrm{m}$.

contain both a CCK and a substance P immunoreactive peptide (Skirboll et al., 1982b).

Evidence is also presented here from retrograde tracing studies that some of the cells in this CCK-substance P system descends to the cervical spinal cord, although projections to other areas cannot be excluded. However, the exact sites of termination of these fibers within the spinal cord are not known. It is well known that CCKand substance P-like immunoreactivities are localized in the dorsal horn of the spinal cord (Hökfelt et al., 1975a, b, 1976; Larsson and Rehfeld, 1979). Thus, although the size and density of terminal fibers prohibit a definitive statement with regard to coexistence in nerve terminals, analysis of adjacent thin sections stained with CCK and substance $P$, respectively, reveals a very close overlap between the two immunostains (Hökfelt et al; 1980a; Jansco et al., 1981). The majority of this substance P immunoreactivity present in the dorsal horn has its origin in spinal ganglia (Hökfelt et al., 1975a, 1977; Takahashi and Otsuka, 1975; Barber et al., 1979). The CCK immu- 
noreactivity seen with immunohistochemistry in this area may also mainly be of sensory origin, because CCKpositive cells have recently been observed in spinal ganglia of the rat (Dalsgaard et al., 1982). Interestingly, also in these primary sensory neurons CCK and substance Plike peptides seem to coexist (Dalsgaard et al., 1982). Treatment with capsaicin, which causes a degeneration of small-sized sensory neurons (Jansco et al., 1977, 1981, Nagy et al., 1980), such as substance P-containing fibers (Jessell et al., 1978), results in a parallel loss of CCK and substance $P$ immunoreactive fibers in the dorsal horn (Jansco et al., 1981). Because capsaicin does not deplete cither immunohistochemically detectable CCK or substance $\mathrm{P}$ completely, the mesencephalic CCK-substance $P$ cells described herein may account for some of the immunoreactivity in the dorsal horn. However, it cannot be ruled out these $\mathrm{CCK}$-substance $\mathrm{P}$ cells project to areas other than the dorsal horn.

Although these data suggest that dorsal horn CCK and substance $\mathbf{P}$ mainly derive from primary sensory neurons, recent findings by Schultzberg et al. (1982) using radioimmunoassay (RIA) have shown that capsaicin treatment causes a marked depletion of substance $\mathrm{P}$ but not of CCK in the dorsal horn. This raises the possibility that CCK detected by immunocytochemistry may be a different peptide from the CCK distinguished by RIA. It seems, therefore, necessary to define more exactly the CCK-like immunoreactivity which has been shown to be present in primary sensory neurons as well as in the mesencephalic periaqueductal grey.

It is interesting to note that in the present coexistence situation, the cells that contain two peptides are unique to a particular cell group and neuroanatomical structure. Thus, it must be emphasized that, although both CCKand substance P-like peptides are widely distributed in the central nervous system of the rat, a rough comparison of the distribution patterns of cell bodies containing the two peptides in the rat brain, as described in extensive maps, reveals no other clear incidence of coexistence (for substance P, see Cuello and Kanazawa, 1978; Ljungdahl et al., 1978; for CCK, see Innis et al., 1979; Larsson and Rehfeld, 1979; Loren et al., 1979; Vanderhaeghen et al., 1980). Thus, with the above-mentioned exception of some primary sensory neurons, the present case of coexistence in the periaqueductal central grey seems to be an uncommon feature where these two peptides are concerned. Similarly, although avian pancreatic polypeptide (APP)posilive and somatostatin (SOM)-posilive cell bodies can be found in a variety of brain structures, their presence in the same neuron is limited to cells in the striatum, olfactory tubercle, and neocortex (Vincent et al., 1982). This "cell group" specificity also extends into coexistence situations in which a peptide resides in the same cell as a classical neurotransmitter. For example, substance $P$ coexists with serotonin (5-HT) only in the raphe medullaris despite numerous areas which are rich in either substance P- or 5-HT-containing neurons (see Hökfelt et al., 1978). Furthermore, coexistence does not seem to be universal phenomenon even within a cell group, i.e., not every CCK cell in the periaqueductal grey may be substance $\mathrm{P}$ immunoreactive much in the same way that not every dopamine cell within the ventral tegmentum seems to contain a CCK-like peptide (Hökfelt et al., 1980c). Thus, cells which show evidence for coexistence may, therefore, describe a subpopulation of neurons within a neuroanatomically defined group, i.e., a coexisting peptide may serve to subdivide a transmitter homogeneous neuron population into subclasses.

The presence of two different peptides in the same neuron is not a new finding. Several years ago it was recognized that certain hypothalamic neurons contain both adrenocorticotropic hormone (ACTH) and $\beta$-endorphin (Bloch et al., 1978; Watson et al., 1978; Nilaver et al., 1979; Sofroniew, 1979). Furthermore, in the gastrointestinal tract of the guinea pig SOM- and gastrin/CCKlike peptides occur in the same neurons in the submucous plexus (Schultzberg et al., 1980). In the spinal cord, an APP and an enkephalin-like peptide coexist (Hunt et al., 1981), and some spinal neurons in the medullary raphe nuclei seem to contain a substance $P$ - and a thyrotropin releasing hormone (TRH)-like peptide (Johansson et al., 1981). Finally, a SOM- and an APP-like peptide have been observed in certain telencephalic neurons (Vincent et al., 1982). Whereas in the first case, i.e., coexistence of ACTH and $\beta$-endorphin, there is evidence that these two peptides share a common precursor (Mains et al., 1977; Roberts and Herbert, 1977; Nakanishi et al., 1979), no such relationship has been shown in the latter cases. There is also no evidence for a common precursor for CCK and substance $P$.

The present findings and those cited above indicate that neurons have the ability to produce more than one peptide. Because until now most neurons have only been found to contain a single peptide (or perhaps family of similarly structured peptides which cross-react with a particular antisera), it may be that a "peptide neuron" usually possesses one peptide. Alternatively, "peptide neurons" may normally produce more than one peptide, and these "single peptide neurons" may actually contain additional peptides which still are unknown. The possibility must also be considered that the immunohistochemical technique is not sufficiently sensitive to visualize very low contents of peptides, and one may, therefore, detect only those present in comparatively high concentrations. Finally, the possibility that peptide levels are a function of neuronal activity at the time of fixation cannot be ruled out. Thus, the uniqueness of coexistence to particular cells or cell groups may only be a description of cell function and/or activity and may then ultimately prove to be a more universal phenomenon than presently described.

The functional significance of the presence of both these peptides in single periaqueductal grey cells is, as yet, unknown. There are, however, several physiological parallels which link the actions of these two peptides. Electrophysiologically, both substance $\mathrm{P}$ and CCK-like peptides have been shown to have a depolarizing and/or excitatory action on neuronal activity (for substance $P$, Otsuka and Takahaski, 1977; Randic and Miletic, 1977; Phillis and Kirkpatrick, 1979; Dodd and Kelly, 1979, 1981; Nicoll et al., 1980; Jeftinija et al., 1981; Skirboll et al., 1981). In addition, the periaqueductal central grey has been shown to be an effective stimulation site for producing analgesia, a finding which has given rise to the 
suggestion that a descending system may well be involved (Basbaum and Fields, 1978). We provide evidence here that there are descending periaqueductal grey projections in the rat similar to those described in the cat and monkey (Kuypers and Maisky, 1975; Castiglioni et al., 1978; Maisky and Kuypers, 1978; Basbaum and Fields, 1979; Tohyama et al., 1979; Watkins et al., 1981; see also Bowker et al., 1981), some of which contain both CCKlike peptides and substance $P$. In light of this finding, it is of particular interest that there is evidence that both substance P (Stewart et al., 1976; Frederickson et al., 1978; Malick and Goldstein, 1978; Mohrland and Gebhart, 1979) and CCK-like peptides (Mohrland and Gebhart, 1979; Zetler, 1980, Jurna and Zetler, 1981) can elicit a naloxone-sensitive analgesia in rats. In this regard, a physiological role for both substance $P$ and CCK by which each of these peptides acts by releasing an endogenous opioid substance has been proposed by independent investigators (Krivoy et al., 1977; Frederickson et al., 1978; Malick and Goldstein, 1978; Zetler, 1980). Whether the CCK-substance $\mathrm{P}$ system described herein is the one responsible for the ability of these two peptides to alter reactions to noxious stimuli, however, remains to be determined.

In conclusion, two peptides have been demonstrated in a single neuron, and it may be speculated that the release of more than one mediator makes it possible to convey more differentiated messages and perhaps to control in a more subtle way the synaptic transmission process. Similar speculations have been advanced also when discussing the role of a coexisting classical transmitter and a peptide (see Hökfelt et al., 1980a).

\section{References}

Barber, R., J. Vaughn, J. Slemmon, P. Salvaterra, E. Roberts, and S. Leeman (1979) The origin, distribution and synaptic relationships of Substance $\mathrm{P}$ axons in rat spinal cord. $\mathrm{J}$. Comp. Neurol. 184: 331-352.

Basbaum, A. I., and H. L. Fields (1978) Endogenous pain control mechanisms: Review and hypothesis. Ann. Neurol. 4: 451462.

Basbaum, A. I., and H. L. Fields (1979) The origin of descending pathways in the dorsolateral funiculus of the spinal cord of the cat and rat: Further studies on the anatomy of pain modulation. J. Comp. Neurol. 187: 513-532.

Bloch, B., C. Bugnon, D. Fellman, and D. Lenys (1978) Immunocytochemical evidence that the same neurons in the human infundibular nucleus are stained with anti-endorphin and antisera of other related peptides. Neurosci. Lett. 10: 147152.

Bowker, R. M., K. N. Westlund, and J. D. Coulter (1981) Origins of serotonergic projections to the spinal cord in rat: An immunocytochemical-retrograde transport study. Brain Res. 226: 187-199.

Castiglioni, A. J., M. C. Gallaway, and J. D. Coulter (1978) Spinal projections from the midbrain in the monkey. J. Comp. Neurol., 278: 329-346.

Chang, M. M., S. E. Leeman, and H. D. Niall (1971) Amino acid sequence of substance P. Nature New Biol. 232: 86-87.

Coons, A. H. (1958) Fluorescent antibody methods. In General Cytochemical Methods, J. F. Danielli, ed., pp. 399-422, Academic Press, Inc., New York.

Cuello, A. C., and I. Kanazawa (1978) The distribution of substance $\mathrm{P}$ immunoreactive fibers in the rat central nervous system. J. Comp. Neurol. 178: 129-156.
Cuello, A. C., C. Milstein, and J. V. Priestly (1980) Use of monoclonal antibodies in immunocytochemistry with special reference to the central nervous system. Brain Res. Bull. 5: 575-587.

Dalsgaard C. J., S. R. Vincent, T. Hökfelt, J. M. Lundberg, A. Dahlström, M. Schultzberg, G. J. Dockray, and A. C. Cuello (1982) Coexistence of cholecystokinin- and substance P-like peptides in neurons of the dorsal root ganglia of the rat. Neurosci. Lett. 33: 159-164.

Dockray, G. J., R. G. Williams, and W. Y. Zhu (1981) Development of region specific antisera for the C-terminal tetrapeptide of gastrin/cholecystokinin and their use in studies of immunoreactive forms of cholecystokinin in rat brain. Neurochem. Int. 3: 281-288.

Dodd, J., and J. S. Kelly (1979) Excitation of CAl pyramidal neurones of the hippocampus by the tetra- and octapeptide C-terminal fragments of cholecystokinin. J. Physiol. (Lond.) 295: 61P-62P.

Dodd, J., and J. Kelly (1981) The actions of cholecystokinin and related peptides on pyramidal neurons of the mammalian hippocampus. Brain Res. 205: 337-350.

Frederickson, R. C. A., V. Burgis, C. E. Harel, and J. D. Edwards (1978) Dual actions of substance P on nociception: Possible role of endogenous opioids. Science 199: 1359-1361.

Hökfelt, T., J. O. Kellerth, G. Nilsson, and B. Pernow (1975a) Experimental immunohistochemical studies on the localization and distribution of substance $P$ in cat primary sensory neurons. Brain Res. 100: 235-252.

Hökfelt, T., J. O. Kellerth, G. Nilsson, and B. Pernow (1975b) Substance $P$ localization in the central nervous system and in some primary sensory neurons. Science 198: 889-890.

Hökfelt, T., R. Elde, O. Johansson, R. Luft, G. Nilsson, and A. Arimura (1976) Immunohistochemical evidence for separate populations of somatostatin containing and substance $P$ containing primary afferent neurones in the rat. Neuroscience 1: 131-136.

Hökfelt, T., A. Ljungdahl, L. Terenius, R. Elde, and G. Nilsson (1977) Immunohistochemical analysis of peptide pathways possibly related to pain and analgesia: Enkephalin and substance P. Proc. Natl. Acad. Sci. U. S. A. 74: 3081-3085.

Hökfelt, T., A. Ljungdahl, H. Steinbusch, A. Verhofstad, G. Nilsson, E. Brodin, B. Pernow, and M. Goldstein (1978) Immunohistochemical evidence of substance P-like immunoreactivity in some 5-hydroxytryptamine containing neurons in the rat central nervous systam. Neuroscience 3: 517538.

Hökfelt, T., O. Phillipson, H. G. J. M. Kuypers, M. Bentivoglio, C. Catsman-Berrevoets, and O. Dann (1979) Tracing of transmitter histochemically identified neuron projections: Immunohistochemistry combined with fluorescent retrograde labeling. Neurosci. Lett (Suppl.) 3: 342.

Hökfelt, T., O. Johansson, $\AA$. Ljungdahl, J. Lundberg, and M. Schultzberg (1980a) Peptidergic neurons. Nature 284: 515521.

Hökfelt, T., J. Lundberg, M. Schultzberg, O. Johansson, A. Ljungdahl, and J. Rehfeld (1980b) Co-existence of peptides and putative neurotransmitters in neurons. In Neural Peptides and Neuronal Communication, E. Costa and M. Trabucchi, eds., Raven Press, New York.

Hökfelt, T., L. Skirboll, J. F. Rehfeld, M. Goldstein, K. Markey, and O. Dann (1980c) A subpopulation of mesencephalic dopamine neurons projecting to limbic areas contains a cholecystokinin-like peptide: Evidence from immunohistochemistry combined with retrograde tracing. Neuroscience 5: 20932124.

Hunt, S. P., P. C. Emson, R. Gilbert, M. Goldstein, and J. R. Kimmel (1981) Presence of avian pancreatic polypeptide-like immunoreactivity in catecholamine and methionine-enkeph- 
alin-containing neurons within the central nervous system. Neurosci. Lett. 21: 125-130.

Innis, R. B., F. M. Correa, G. Uhl, B. Schneider, and S. H. Snyder (1979) Cholecystokinin octapeptide immunoreactivity. Histochemical localization in the rat brain. Proc. Natl. Acad. Sci. U. S. A. 76: 521-525.

Jancso, G., E. Kiraly, and A. Jancso-Gabor (1977) Pharmacologically induced selective degeneration of chemosensitive primary sensory neurons. Nature 270: 741-743.

Jancso, G., T. Hökfelt, J. Lundberg, E. Kiraly, N. Halasz, G. Nilsson, L. Terenius, J. Rehfeld, A. Steinbusch, R. Verhofstad, R. Elde, S. Said, and M. Brown (1981) Effect of capsaicin on peptide and monoamine neurons using antisera to substance $\mathrm{P}$, gastrin/CCK, somatostatin, VIP, enkephalin, neurotensin and 5-hydroxytryptamine. J. Neurocytol. 10:963980.

Jeftinija, S., V. Miletic, and M. Randic (1981) Cholecystokinin octapeptide excites dorsal horn neurons both in vivo and in vitro. Brain Res. 212: 231-236.

Jessell, T. M., L. L. Iversen, and C. Cuello (1978) Capsaicininduced depletion of substance $P$ from primary sensory neurones. Brain Res. 152: 183-188.

Johansson, O., T. Hökfelt, B. Pernow, S. Jeffcoate, N. White, H. Steinbusch, A. Verhofstad, P. Emson, and E. Spindel (1981) Immunohistochemical support for three putative transmitters in one neuron: Substance-P and thyrotropin releasing hormone-like immunoreactivity in medullary neurons projecting to spinal cord. Neuroscience 6: 1857-1881.

Jurna, I., and G. Zetler (1981) Antinociceptive effect of centrally administered caerulein and cholecystokinin octapeptide (CCK-8). Eur. J. Pharmacol. 73: 323-331.

Krivoy, W. A., D. C. Kroeger, and E. Zimmerman (1977) Neuropeptides: Influence of acute and chronic effects of opiates. Psychoneuroendocrinology 2: 43-52.

Kuypers, H. G. J. M., and V. Maisky (1975) Retrograde axonal transport of horseradish peroxidase from spinal cord to brainstem cell groups in the cat. Neurosci. Lett. 1: 9-14.

Kuypers, H. G. J. M., C. Catsman-Berrevoets, and R. E. Padt (1977) Retrograde axonal transport of fluorescent substances in rat forebrain. Neurosci. Lett. 6: 127-135.

Larsson, L. I., and J. F. Rehfeld (1979) Localization and molecular heterogeneity and cholecystokinin in the central and peripheral nervous system. Brain Res. 165: 201-218.

Ljungdahl, A., T. Hökfelt, and G. Nilsson (1978) Distribution of substance $P$ like immunoreactivity in the central nervous system of the rat. I. Cell bodies and nerve terminals. Neuroscience 3: 945-976.

Loren, I., L. Alumets, R. Hakanson, and F. Sundler (1979) Distribution of gastrin and CCK-like peptides in rat brain. An immunocytochemical study. Histochemistry 59: 249-257.

Mains, R. E., B. E. Eipper, and N. Ling (1977) Common precursor to corticotropins and endorphins. Proc. Natl. Acad. Sci. U. S. A. 74: 3014-3018.

Maisky, V. A., and H. J. Kuypers (1978) Studies of the supraspinal system neurons in the cat brain by the technique of horseradish peroxidase. Neirofiziologiia 10: 115-124.

Malick, J. B., and J. M. Goldstein (1978) Analgesic activity of substance $P$ following intracerebral administration in rats. Life Sci. 23: 835-844.

Mohrland, J. S., and G. F. Gebhart (1979) Substance P induced analgesia in the rat. Brain Res. 171: 556-559.

Nagy, J., S. Vincent, W. Staines, H. Fibiger, T. Reisine, and H. Yamamura (1980) Neurotoxic action of capsaicin on spinal Substance P neurons. Brain Res. 186: 435-444.

Nakanishi, S., A. Inoue, T. Kita, S. Numa, A. C. Change, S. N. Cohen, J. Nunberg, and R. T. Schimke (1979) Nucleotide sequence of cloned cDNA for bovine corticotropin- $\beta$-lipotropin precursor. Nature 278: 423-427.
Nicoll, R. A., C. Schenker, and S. E. Leeman (1980) Substance $\mathrm{P}$ as a transmitter candidate. Annu. Rev. Neurosci. 3: 227268.

Nilaver, G., E. A. Zimmerman, R. Defendini, A. S. Liotta, D. T. Kreiger, and M. J. Brownstein (1979) Adrenocorticotropin and beta-lipotropin in the hypothalamus. Localization in the same arcuate neurons by sequential immunocytochemical procedures. J. Cell Biol. 81: 50-58.

Otsuka, M., and T. A. Takahashi (1977) Putative peptide neurotransmitters. Annu. Rev. Pharmacol. Toxicol. 17: 425-439.

Phillis, J., and R. Kirkpatrick (1979) Actions of various gastrointestinal peptides on the isolated amphibian spinal cord. Can. J. Physiol. Pharmacol. 57: 887-899.

Randic, M., and V. Miletic (1977) Effect of substance $P$ in cat dorsal horn neurons activated by noxious stimuli. Brain Res. 128: $164-169$.

Rehfeld, J. F. (1981) A unique high titre antiserum to gastrin. Scand. J. Clin. Lab. Invest. 41: 723-727.

Roberts, J. S., and E. Herbert (1977) Characterization of a common precursor to corticotropin and $\beta$-lipotropin: Identification of $\beta$-lipotropin peptides and their arrangement relative to corticotropin in the precursor synthesized in a cellfree system. Proc. Natl. Acad. Sci. U. S. A. 74: 5300-5304.

Schultzberg, M., T. Hökfelt, G. Nilsson, L. Terenius, J. Rehfeld, R. Elde, M. Goldstein, and S. Said (1980) Distribution of peptide- and catecholamine-containing neurons in the gastrointestinal tract of rat and guinea pig: Immunohistochemical studies with antisera to substance $P$, vasoactive intestinal polypeptide, enkephalins, somatostatin, gastrin/cholecystokinin, neurotensin and dopamine beta-hydroxylase. Neuroscience 5: 689-744.

Schultzberg, M., G. Dockray, and R. Williams (1982) Capsaicin depletes CCK-like immunoreactivity detected by immunohistochemistry but not that measured by radioimmunoassay in the rat dorsal spinal cord. Brain Res. 235: 198-204.

Skirboll, L., and T. Hökfelt (1982) Transmitter specific mapping of neuronal pathways: Immunocytochemistry combined with fluorescent dyes. In IBRO Handbook-Methods in Neurosciences, C. Cuello, ed., John Wiley \& Sons, New York, 1983.

Skirboll, L., A. A. Grace, D. W. Hommer, J. Rehfeld, M. Goldstein, T. Hökfelt, and B. S. Bunney (1981) Peptide monoamine co-existence: Studies of the actions of cholecystokinin-like peptide on the electrical activity of midbrain dopamine neurons. Neuroscience 6: 2111-2124.

Skirboll, L., T. Hökfelt, H. G. J. M. Kuypers, M. Bentivoglio, C. Catsman-Berrevoets, O. Dann, M. Goldstein, J. Rehfeld, H. Steinbusch, A. Verhofstad, P. Emson, L. Terenius, and O. Phillipson (1982a) A method for combining immunohistochemistry with retrogradely transported dyes: Transmitter specific mapping of neuronal pathways. Submitted for publication.

Skirboll, L., T. Hökfelt, J. Rehfeld, A. C. Cuello, and G. Dockray (1982b) Co-existence of Substance P- and cholecystokininlike immunoreactivity in neurons of the mesencephalic periaqueductal central grey. Neurosci. Lett. 28: 35-39.

Snyder, S. H. (1980) Brain peptides as neurotransmitters. Science, 209: 976-983.

Sofroniew, M. V. (1979) Immunoreactive $\beta$-endorphin and ACTH in the same neurons of the hypothalamic arcuate nucleus in the rat. Am. J. Anat. 154: 280-289.

Stewart, J. M., C. J. Getto, K. Neldner, E. B. Reeve, W. A. Krivoy, and E. Zimmerman (1976) Substance P and analgesia. Nature 262: 784-785.

Takahashi, T., and M. Otsuka (1975) Regional distribution of Substance $\mathrm{P}$ in the spinal cord and nerve roots of the cat and the effect of dorsal root section. Brain Res. 87: 1-11.

Tohyama, M., K. Sakai, M. Touret, D. Salvert, and M. Jouvet (1979) Spinal projections from the lower brain stem in the 
cat as demonstrated by the horseradish peroxidase technique. II. Projections from the dorsolateral pontine tegmentum and raphe nuclei. Brain Res. 176: 215-221.

Tramu, G., A. Pillez, and J. Leonardelli (1978) An efficient method of antibody elution for the successive or simultaneous location of two antigens by immunocytochemistry. J. Histochem. Cytochem. 25: 322-324.

Vanderhaeghen, J. J., J. C. Signeau, and W. Gepts (1975) New peptide in the vertebrate CNS reacting with gastrin antibodies. Nature 221: 557-559.

Vanderhaeghen, J. J., F. Lotstra, J. de May, and C. Gilles (1980) Immunohistochemical localization of cholecystokinin and gastrin-like peptides in the brain and hypophysis of the rat. Proc. Natl. Acad. Sci. U. S. A. 77: 1190-1194.

Vincent, S. R., L. R. Skirboll, T. Hökfelt, O. Johansson, J. Lundberg, R. Elde, and L. Terenius (1982) Coexistence of somatostatin- and avian pancreatic polypeptide (APP)-like immunoreactivity in some forebrain neurons. Neuroscience 7: 439-446.

Von Euler, U. S., and J. N. Gaddum (1931) An unidentified supressor substance in certain tissue extracts. J. Physiol. (Lond.) 72: 74-87.

Watkins, L. R., G. Griffin, G. R. Leichnetz, and D. J. Mayer, (1981) Identification and somatotopic organization of nuclei projecting via the dorsolateral funiculus in rats: A retrograde tracing study using HRP slow-release gels. Brain Res. 223: 237-255.

Watson, S. J., H. Akil, C. W. Richard, III, and J. D. Barchas (1978) Evidence for two separate opiate peptide neuronal systems. Nature 275: 226-228.

Zetler, G. (1980) Analgesia and ptosis caused by caerulein and cholecystokinin octapeptide (CCK-8). Neuropharmacology 19: 415-422. 